\title{
Increasing Dietary Levels of Cracked Pima Cottonseed Increase Plasma Gossypol but do not Influence Productive Performance of Lactating Holstein Cows
}

\author{
J. G. Prieto, ${ }^{\star}$ E. J. DePeters, ${ }^{*}$ P. H. Robinson, ${ }^{\star}$ J. E. P. Santos, $\dagger$ \\ J. W. Pareas, ${ }^{\star}$ and S. J. Taylor* \\ *Department of Animal Science \\ University of California at Davis, Davis, CA 95616-8521 \\ †Veterinary Medicine Teaching and Research Center \\ University of California at Davis, Tulare, CA 93274
}

\section{ABSTRACT}

Lactating Holstein cows were fed diets with increasing levels of cracked Pima cottonseed to determine its effects on plasma gossypol concentrations as well as milk yield and composition and dry matter (DM) intake in a short-term study. All diets contained $12.8 \%$ cottonseed, $43.5 \%$ concentrate, and $43.7 \%$ chopped alfalfa hay on a DM basis. The proportion of whole Upland cottonseed to cracked Pima cottonseed in the four diets was 100:0, 67:33, 33:67, and 0:100. Four primiparous cows were fed the diets in a $4 \times 4$ Latin square design, and three multiparous cows were fed the diets in a Youden square design with five periods. All periods were $35 \mathrm{~d}$. Upland and cracked Pima cottonseed contained 0.64 and $1.00 \%$ total gossypol (DM) with 41 and $52 \%$ of gossypol as the (-) isomer, respectively. Gossypol is a natural defense compound in the plant that protects it against pests and diseases, but can have antinutritional quality effects when consumed by dairy cattle. Total plasma gossypol concentrations increased linearly with increasing proportions (100:0,67:33, 33:67, and 0:100) of cracked Pima cottonseed in the diet for primiparous $(4.4,6.0,7.7$, and $8.9 \mu \mathrm{g} / \mathrm{ml})$ and multiparous (4.3, 7.3, 9.7 , and $11.4 \mu \mathrm{g} / \mathrm{ml}$ ) cows, respectively. While primiparous cows responded similarly to gossypol intake, the response of plasma gossypol intake in multiparous cows differed among cows. This indicates the importance of animal variation when relating plasma gossypol levels with gossypol intake. Milk yield, as well as its components and DM intake, were not affected by increasing dietary inclusion levels of cracked Pima cottonseed up to $8.6 \%$ of DM intake for either primiparous or multiparous cows, even though plasma gossypol concentrations increased sharply over this dietary inclusion range. Al-

\footnotetext{
Received November 5, 2001

Accepted February 22, 2002.

Corresponding author: E. DePeters, e-mail: ejdepeters@ucdavis.
} edu. though the highest dietary inclusion level of Pima cottonseed (i.e., 12.8\%) numerically depressed performance of cows of both parities, these differences failed to reach statistical significance in these short-term trials with few cows.

(Key words: Pima cottonseed, Upland cottonseed, gossypol, milk yield)

Abbreviation key: CLA = conjugated linoleic acid; $\mathbf{C r P}=$ cracked Pima cottonseed; $\mathbf{F A}$ = fatty acid; $\mathbf{S S}=$ short staple cottonseed; PUN = plasma urea nitrogen; TG = total gossypol; WCS = whole Upland cottonseed; $\mathbf{W P}=$ whole Pima cottonseed.

\section{INTRODUCTION}

Whole cottonseed has long been used as a source of $\mathrm{CP}$, fiber, and energy in the diet of dairy cows (Noftsger et al., 2000). Upland cotton (Gossypium hirsutum) produces traditional whole cottonseed (WCS), widely used in dairy rations, which is often called "fuzzy seed" because of the lint covering the seed. However, production of Pima cotton ( $G$. barbedense) has increased because of the extra long staple length of the cotton, which is desired for the manufacturing properties of cotton fiber. Pima cottonseed (WP), which is naturally devoid of lint, is higher in oil and CP and lower in fiber than Upland seed (Sullivan et al., 1993a).

Cottonseed contains gossypol, a toxic compound that exhibits acidic, phenolic, and aldehydic properties (Blauwiekel et al., 1997). Gossypol occurs throughout the cotton plant as a natural defense against insect pests, but it is concentrated in pigment glands present in the seeds. Gossypol exists as a mixture of (+) and (-) stereoisomers. The (-) isomer appears to have higher biological activity (Joseph et al., 1986). Calhoun et al. (1995a) reported similar values for total gossypol (TG), but higher concentrations of the (-) isomer in WP than in WCS.

Mature ruminants, which possess a functioning rumen, can detoxify gossypol, and the ability to metaboli- 
cally tolerate gossypol coincides with the development of rumen function (Calhoun and Holmberg, 1991). It was long believed that the mechanism of gossypol detoxification by ruminants was by its binding to soluble proteins and that the bond was resistant to enzymatic digestion (Reiser and Fu, 1962). However, Coppock et al. (1987) reported that multiple mechanisms, as yet incompletely defined, are probably operative in gossypol detoxification. Calhoun et al. (1995b) also proposed that the detoxification of free gossypol, which occurs when cotton byproducts containing gossypol are fed to ruminants, is not due solely to its binding to soluble proteins and the free $\varepsilon$-amino groups of lysine. The free gossypol released during digestion of cottonseed in the rumen is mostly unavailable for absorption in the small intestine, whereas availability in the small intestine is greatly enhanced when gossypol escapes the rumen intact (Calhoun et al., 1995b). Many effects of gossypol toxicity occur in animals, but alterations in normal erythrocyte structure (membrane damage), metabolism (decrease hemoglobin), and/or function (effect on normal oxygen exchange) appear to be the major physiological effects of gossypol in lactating dairy cows (Lindsey et al., 1980).

Numerous studies have demonstrated beneficial effects of feeding whole Upland cottonseed (WCS) on the yield of milk and milk fat of lactating dairy cows (Anderson et al., 1979; Smith et al., 1981; DePeters et al., 1985; Harrison et al., 1995). However much less research data are available describing the feeding value of Pima cottonseed.

A potential problem associated with feeding of whole Pima cottonseed (WP) is the appearance of undigested whole seed in feces (Osland and Wagner, 1985). Therefore Pima cottonseed is generally processed by either cracking or grinding before being fed to dairy cattle. Feeding processed Pima cottonseed to lactating cows has resulted in comparable production performance as WCS (Sullivan et al., 1993a; 1993b). However the intestinal availability of gossypol and its ability to produce a toxic response can increase when cottonseed is processed before feeding (Calhoun et al., 1995a).

The objective of this study was to determine the effects of replacing WCS with increasing proportions of cracked Pima cottonseed (CrP), up to $12.8 \%$ of diet DM, on plasma gossypol levels, as well as DMI, milk production, and composition of lactating primiparous and multiparous dairy cows.

\section{MATERIALS AND METHODS}

\section{Cows, Experimental Design, Diets, and Treatments}

Seven lactating Holstein cows, four primiparous and three multiparous, were used. Primiparous cows were
Table 1. Average nutrient composition, fatty acid composition, and gossypol content of whole Upland cottonseed (WCS), whole Pima cottonseed (WP) and cracked Pima cottonseed (CrP).

\begin{tabular}{lllll}
\hline & WCS & WP & CrP & SE \\
\hline Nutrient, \% DM & & & & \\
CP & 21.4 & 23.9 & 23.6 & 0.88 \\
ADF & 37.78 & 34.6 & 37.9 & 1.40 \\
NDF & 48.5 & 48.2 & 51.5 & 1.15 \\
EE $^{1}$ & $20.9^{\mathrm{a}}$ & $22.9^{\mathrm{b}}$ & $20.1^{\mathrm{a}}$ & 0.54 \\
DM & 92.4 & 91.8 & 91.7 & 0.26 \\
Fatty acid, \% DM & & & & \\
14:0 & 0.12 & 0.11 & 0.10 & 0.01 \\
16:0 & 3.60 & 3.67 & 3.35 & 0.26 \\
18:0 & $0.37^{\mathrm{a}}$ & $0.45^{\mathrm{b}}$ & $0.40^{\mathrm{ab}}$ & 0.03 \\
18:1 & $2.51^{\mathrm{a}}$ & $2.97^{\mathrm{b}}$ & $2.69^{\mathrm{ab}}$ & 0.21 \\
18:2 & 8.32 & 8.06 & 7.33 & 0.64 \\
Total fatty acids & 18.88 & 19.23 & 17.68 & 1.41 \\
Gossypol (HPLC) & & & & \\
Total, \% of DM & $0.64^{\mathrm{a}}$ & $0.97^{\mathrm{b}}$ & $1.00^{\mathrm{b}}$ & 0.07 \\
(-)-gossypol, \% of total gossypol & $41.14^{\mathrm{a}}$ & $51.83^{\mathrm{b}}$ & $51.97^{\mathrm{b}}$ & 1.98 \\
(+)-gossypol, \% of total gossypol & $58.86^{\mathrm{a}}$ & $48.17^{\mathrm{b}}$ & $48.03^{\mathrm{b}}$ & 1.98 \\
\hline
\end{tabular}

${ }^{\mathrm{a}, \mathrm{b}}$ Means (four samples) within the same row with different superscripts differ $(P<0.05)$.

${ }^{1}$ Ether extract.

${ }^{2}$ Number of carbons:number of double bonds.

fed the diets in a $4 \times 4$ Latin square experimental design, whereas multiparous cows were fed the diets in a $5 \times 3$ Youden square design. Primiparous cows averaged $100 \pm 12$ DIM at the start of the study and had a mean initial BW of $586 \pm 79 \mathrm{~kg}$. Multiparous cows averaged $70 \pm 17 \mathrm{~d}$ in milk at the start with a mean initial BW of $629 \pm 41 \mathrm{~kg}$. Each experimental period was $5 \mathrm{wk}$ in duration, with wk 4 and 5 used for collection of data. The experiment was initiated on April 4, 2000.

Four diets were formulated to contain $12.8 \%$ cottonseed (DM basis). Proportions of WCS to CrP were: 100:0, 67:33, 33:67, and 0:100. Whole Pima cottonseed was rolled at the Feed Mill Facility at University of California, Davis to create the $\mathrm{CrP}$, and $\mathrm{CrP}$ had a mean particle size of $3.58 \mathrm{~mm}$. The chemical composition of the WCS, WP, and CrP is in Table 1. Cottonseeds were also analyzed for fatty acid (FA) composition and gossypol. Ingredient and chemical composition of each TMR are described (Table 2).

Cows were housed in outdoor corrals with covered free stalls bedded in sand and a concrete-paved exercise area and walk lanes. The Animal Use and Care Administrative Committee of the University of California at Davis approved care of the cows. Cows had free access to water and were fed twice daily ad libitum, at approximately 0730 and $1930 \mathrm{~h}$, following milking using individual feeding gates (American Calan Inc., Northwood, $\mathrm{NH})$. Diets were sampled daily during wk 4 and 5 of each period and composited by week. A portion of each composite was oven dried at $100^{\circ} \mathrm{C}$ for $16 \mathrm{~h}$ to determine its DM content. The remainder of the sample was air- 
PRIETO ET AL.

Table 2. Actual ingredient and chemical composition of diets (DM basis).

\begin{tabular}{|c|c|c|c|c|c|c|c|}
\hline & \multicolumn{4}{|c|}{ WCS:CrP ${ }^{1}$} & \multirow[b]{2}{*}{$\mathrm{SE}$} & \multicolumn{2}{|c|}{ Effects $^{2}$} \\
\hline & $100: 0$ & $67: 33$ & $33: 67$ & $0: 100$ & & $\mathrm{~L}$ & $\mathrm{Q}$ \\
\hline & & & & & & $\longrightarrow$ & $\longrightarrow$ \\
\hline \multicolumn{8}{|l|}{ Ingredient composition: } \\
\hline Alfalfa hay, chopped & 43.7 & 43.7 & 43.7 & 43.7 & & & \\
\hline Beet pulp, shredded & 15.5 & 15.5 & 15.5 & 15.5 & & & \\
\hline Corn grain, flaked & 8.7 & 8.7 & 8.7 & 8.7 & & & \\
\hline Barley grain, rolled & 8.9 & 8.9 & 8.9 & 8.9 & & & \\
\hline Molasses liquid, cane & 6.0 & 6.0 & 6.0 & 6.0 & & & \\
\hline Mineral-vitamin supplement ${ }^{3}$ & 2.1 & 2.1 & 2.1 & 2.1 & & & \\
\hline Yellow grease & 2.3 & 2.3 & 2.3 & 2.3 & & & \\
\hline Upland cottonseed, whole & 12.8 & 8.5 & 4.3 & 0.00 & & & \\
\hline Pima cottonseed, cracked & 0.0 & 4.3 & 8.5 & 12.8 & & & \\
\hline \multicolumn{8}{|l|}{ Chemical composition (DM basis): } \\
\hline Ash & 9.88 & 9.95 & 10.13 & 9.99 & 0.99 & 0.71 & 0.73 \\
\hline $\mathrm{CP}$ & 16.99 & 16.84 & 16.91 & 16.87 & 0.94 & 0.78 & 0.82 \\
\hline $\mathrm{EE}^{4}$ & 5.90 & 6.16 & 6.11 & 6.46 & 0.47 & 0.02 & 0.74 \\
\hline $\mathrm{NDF}$ & 36.22 & 36.53 & 35.75 & 36.16 & 2.07 & 0.75 & 0.94 \\
\hline $\mathrm{ADF}$ & 22.45 & 22.24 & 21.75 & 21.94 & 1.14 & 0.22 & 0.58 \\
\hline Cellulose & 17.37 & 16.70 & 16.67 & 16.96 & 1.24 & 0.48 & 0.22 \\
\hline Lignin & 4.52 & 4.55 & 4.47 & 4.90 & 0.47 & 0.10 & 0.17 \\
\hline $\mathrm{Ca}$ & 0.89 & 0.87 & 0.89 & 0.90 & 0.05 & 0.45 & 0.37 \\
\hline $\mathrm{P}$ & 0.36 & 0.37 & 0.36 & 0.35 & 0.03 & 0.23 & 0.21 \\
\hline $\mathrm{Mg}$ & 0.57 & 0.56 & 0.57 & 0.56 & 0.05 & 0.78 & 0.96 \\
\hline
\end{tabular}

${ }^{1}$ WCS:CrP: Proportion of whole Upland cottonseed (WCS) to cracked Pima cottonseed (CrP).

${ }^{2} \mathrm{~L}=$ Linear effect; $\mathrm{Q}=$ quadratic effect.

${ }^{3}$ Guaranteed analysis (\%, except for vitamins A, D, and $\mathrm{E}$ as noted): $\mathrm{Ca}, 13.0 ; \mathrm{P}, 6.0 ; \mathrm{Mg}, 6.36 ; \mathrm{K}, 1.0$; $\mathrm{Na}, 8.03 ; \mathrm{S}, 1.58$; Mn, 0.2; Fe, 0.31; I, 0.0044; Cu, 0.09; Co, 0.0019; Zn, 0.34; Se, 0.0017; biotin, 0.00441; vitamin A, 220,000 IU/kg; vitamin $\mathrm{D}_{3}, 138,800 \mathrm{IU} / \mathrm{kg}$; vitamin E, 1,100 IU/kg. Supplement contained $27.7 \%$ sodium bicarbonate and $11.0 \%$ magnesium oxide ( $\mathrm{Na}$ and $\mathrm{Mg}$ included in guaranteed analysis).

${ }^{4} \mathrm{EE}=$ Ether extract.

dried at room temperature $\left(25^{\circ} \mathrm{C}\right)$ for approximately 96 $\mathrm{h}$, ground through a 1-mm screen using a Wiley mill (Arthur A. Thomas, Philadelphia, PA) and stored at room temperature in sealed plastic containers for later chemical analysis. Feed refusals were determined weekly, and refusals were sampled during wk 4 and 5 of each period. These samples were handled similar to feed samples. While cows were weighed once weekly on a common day, problems with the scale prevented used of the data.

Cows were milked twice daily, at approximately 0700 and $1900 \mathrm{~h}$, and yields were recorded. Samples of milk were collected twice during wk 4 and 5 of each period as evening and morning composites. Westfalia milk meters and samplers (Westfalia, Naperville, IL) were used in the milking parlor. Milk samples were preserved in 2bromo-2-nitro-propane-1,3-diol (Dairy and Food Labs, Inc., Modesto, CA), and kept refrigerated $\left(5^{\circ} \mathrm{C}\right)$ until analysis immediately after the morning collection. At that time, milk samples were placed in a water bath $\left(40^{\circ} \mathrm{C}\right)$, warmed, and the p.m. and a.m. samples of each cow were mixed to create the daily composite. A $10-\mathrm{ml}$ aliquot was frozen $\left(-20^{\circ} \mathrm{C}\right)$ for subsequent analysis of FA composition.

\section{Blood Sampling}

Blood was collected from the coccygeal vein or artery of each cow into a 10-ml Vacutainer tube containing sodium heparin once weekly approximately $2 \mathrm{~h}$ after the morning feeding. Blood samples were placed in ice immediately after collection, kept out of light, and transported to the laboratory within 5 min where samples were centrifuged at $3000 \times g$ for $10 \mathrm{~min}$. Plasma was recovered into a $5-\mathrm{ml}$ screw cap mailer tube and stored at $-20^{\circ} \mathrm{C}$ for subsequent gossypol analysis.

In wk 4 and 5 of each period, blood samples were collected from all cows into 10-ml evacuated EDTA blood tubes (Becton Dickinson Vacutainer Systems, Rutherford, NY) just before feeding $(0 \mathrm{~h})$ and at $2 \mathrm{~h}$ postfeeding in a similar manner as described previously. Plasma was stored frozen $\left(-23^{\circ} \mathrm{C}\right)$ until it was thawed and analyzed for NEFA, urea N, and glucose. In addition, a blood sample from each cow was drawn into a heparin-containing tube before the morning milking during wk 5 . These blood samples were placed in ice after collection, transported to the laboratory within $5 \mathrm{~min}$ and used for the determination of erythrocyte fragility index (Dacie and Lewis, 1968). 


\section{Analytical Procedures}

Samples of cottonseed were analyzed for DM, total $\mathrm{N}$, ether extract, ash (AOAC, 1990), NDF (Van Soest et al., 1991), and ADF (Robertson and Van Soest, 1981). Approximately $200 \mathrm{~g}$ of $\mathrm{CrP}$ was sieved for $2 \mathrm{~min}$ in a Ro-Tap Testing Sieve Shaker (model B; C-E Tyler Combustion Engineering, Inc., Bessemer City, NC) at the Veterinary Medicine Teaching and Research facility. Mesh sizes of the sieves used were 5.60, 4.75, 3.75, $2.36,1.70,1.00$, and $0.60 \mathrm{~mm}$ and a bottom pan. The amount of material retained on each sieve was weighed to determine the mean particle size. Samples of cottonseed were analyzed for TG and gossypol isomers by HPLC (Hron et al., 1999) and for free and TG by AOCS official methods $\mathrm{Ba}$ 7-58 and $\mathrm{Ba}$ 8-78 respectively (AOCS, 1985a; 1985b). Individual FA composition and total FA content of the cottonseed was determined as described previously (Avila et al., 2000). Methyl esters of FA were separated and quantified by GLC (HewlettPackard model 5890, equipped with flame-ionization detector at $220^{\circ} \mathrm{C}$ and model $7673 \mathrm{~A}$ auto injector, Palo Alto, CA) using a fused silica capillary column (SP2560, $100 \mathrm{~m} \times 0.25 \mathrm{~mm}$; Supelco, Inc., Bellefonte, PA). The carrier gas was $\mathrm{H}_{2}$ with $0.77 \mathrm{ml} / \mathrm{min}$ flow rate (linear flow rate, $27 \mathrm{~cm} / \mathrm{s}), 220^{\circ} \mathrm{C}$ injector temperature, $1: 88$ split ratio, and constant $175^{\circ} \mathrm{C}$ column temperature. The internal standard was nonadecanoic acid (C19:0; $\mathrm{Nu}$ Chek Prep, Inc., Elysian, MN). Fatty acid peaks were identified by comparison with a standard mixture containing known FA.

Composite ground samples of diets were analyzed for DM, total N, ether extract, ash (AOAC, 1990), NDF (Van Soest et al., 1991), and ADF, cellulose, and lignin (Robertson and Van Soest, 1981). Both $\mathrm{Ca}$ and $\mathrm{Mg}$ in feeds were determined according to (AOAC, 1990), using an Atomic Absorption Spectrometer (Analyst 300, PerkinElmer Instruments) and $\mathrm{P}$ in feed was determined according to a Technicon autoanalyzer method N-4C (Kraml, 1966). Samples of feed refusals remaining during wk 4 and 5 of each period were analyzed similar to the feed samples.

Pooled milk samples from each sample day during wk 4 and 5 were analyzed for fat, protein, lactose, and SNF (AOAC, 1990) with an infrared analyzer and for urea $\mathrm{N}$ by Technicon Autoanalyzer method N-10a (Marsh et al., 1957). Milk samples from one sample day during wk 4 and 5 were analyzed for total FA by GLC (Crocker et al., 1998); for total N, whey protein N, and NPN by Kjeldahl analysis (AOAC, 1990); for total solids by evaporation to dryness on a steam table; and for ash using a muffle furnace at $575^{\circ} \mathrm{C}$ for $8 \mathrm{~h}$. A milk sample from one sample day in wk 5 was analyzed for milk FA in the milk fat globule membrane according to Palmquist and Schanbacher (1991).

Concentrations of NEFA in plasma were quantified using a commercial assay (NEFA-C, Wako Pure Chemicals Industries Ltd., Osaka, Japan). Plasma glucose was analyzed according to Technicon Autoanalyzer method N-2b (Hoffman, 1937), and plasma urea N was determined by Technicon Autoanalyzer method N-10a (Marsh et al., 1957). Erythrocyte osmotic fragility was determined as described by Wise et al. (1991). The effect of gossypol on erythrocyte fragility was determined by using the erythrocyte fragility index (Hawkins et al., 1985), which measures the salt $(\% \mathrm{NaCl})$ concentration at which $50 \%$ hemolysis of erythrocyte occurred.

The energy in milk $\left(\mathrm{NE}_{\mathrm{L}}\right)$ was calculated according to NRC (2001) using the formula based on milk fat, protein, and lactose. Energy intake was estimated as the DM intake of the diets multiplied by their estimated $\mathrm{NE}_{\mathrm{L}}$ contents based on NRC (2001) estimates for each dietary ingredient.

\section{Statistical Analysis}

Nutrient composition of the cottonseeds, as well as nutrient composition of the diets, was statistically analyzed using the general linear models (GLM) procedure of SAS (SAS, 1985).

For primiparous cows, statistical analyses were conducted on the production data using the general linear models procedure of SAS (SAS, 1985) according to the model described by Cochran and Cox (1957) for a $4 \times 4$ Latin square design as:

$$
\mathbf{Y}_{\mathrm{ijkl}}=\boldsymbol{\mu}+\mathbf{T}_{\mathbf{i}}+\mathbf{P}_{\mathbf{j}}+\mathbf{C}_{\mathbf{k}}+\varepsilon_{\mathrm{ijkl}}
$$

Where: $\mathrm{Y}_{\mathrm{ijk}}=$ observation, $\mu=$ population mean, $\mathrm{T}_{\mathrm{i}}=$ diet effect ( $\mathrm{i}=1$ to 4$), \mathrm{P}_{\mathrm{j}}$ = period effect $(\mathrm{j}=1$ to 4$), \mathrm{C}_{\mathrm{k}}$ = cow effect $(\mathrm{k}=1$ to 4$)$, and $\varepsilon_{\mathrm{ijkl}}=$ residual error.

For multiparous cows, the production data were analyzed using the general linear models procedure of SAS (SAS, 1985) according to the model described by Cochran and Cox (1957) and Cox (1958) for a $5 \times 3$ Youden square design:

$$
\mathbf{Y}_{\mathrm{ijq}}=\mu+\pi_{\mathrm{i}}+\beta_{\mathrm{ij}}+\mathbf{T}_{\mathbf{q}}+\mathbf{e}_{\mathbf{j q}}
$$

Where: $\mathrm{Y}_{\mathrm{ijq}}=$ observation, $\mu=$ effects of the population mean, $\pi_{\mathrm{i}}=$ cow effect ( $\mathrm{i}=1$ to 3 ), $\beta_{\mathrm{ij}}=$ period effect $(\mathrm{j}=$ 1 to 5$), T_{q}=\operatorname{diet}$ effect $(q=1$ to 4$)$, and $e_{j q}=$ the intrablock residual or error.

Data on plasma constituents at each sampling time were analyzed by ANOVA using a linear model of SAS (SAS, 1985) that included the main effect of cow, treat- 
ment, sampling time, sampling time $\times$ treatment interaction, and a residual error.

Erythrocyte fragility data were analyzed using the general linear models procedure of SAS (1985) according to the same models utilized for production data. Linear and quadratic effects of treatments were estimated, and significance and trends were declared at $P$ $<0.05$ and $0.05<P<0.10$, respectively.

To identify the probability of relationship between gossypol intake and plasma gossypol, gossypol data were subjected to correlation and regression analysis, using the CORR and REG procedure of SAS (SAS, 1985). The response of plasma gossypol level to gossypol intake for each individual animal was evaluated with the general linear model procedure of SAS (1985) using the Dummy-Variable model.

\section{RESULTS}

The WP was higher $(P<0.05)$ in ether extract than WCS and CrP (Table 1). The WP was higher $(P<0.05)$ in C18:0 and C18:1 than WCS. Total gossypol concentrations were higher $(P<0.05)$ in WP and CrP compared with WCS. Pima cottonseeds were higher $(P<0.05)$ in the $(-)$ isomer and lower $(P<0.05)$ in the $(+)$ isomer than WCS. The WP and CrP were from the same lot sources. Changes in composition might reflect losses of DM occurring during processing or the difficulty of obtaining a representative ground sample of cottonseed for chemical analysis.

Ingredient composition of the TMR was similar, except for the differing proportions of WCS and CrP contributing to the $12.8 \%$ of cottonseed in the diet DM (Table 2). All diets were similar in nutrient composition except for the ether extract content that linearly increased $(P<0.02)$ as the proportion of $\mathrm{CrP}$ increased in the diet. The reason for the increase in $\mathrm{EE}$ content of the diet with the addition of $\mathrm{CrP}$ is unknown, but it may be related to the difficulty of obtaining a representative sample for chemical analysis.

Intakes of DM did not differ among diets for primiparous or multiparous cows (Table 3), and intakes of OM, $\mathrm{CP}, \mathrm{ADF}$, and $\mathrm{EE}$ were similarly unchanged in response to diet (data not shown). Yields of milk and 4\% FCM did not differ among treatments for both parities of cows (Table 3), and efficiency of utilization of $\mathrm{NE}_{\mathrm{L}}$ intake for milk production was similar across treatments for both parities of cows. No differences were found in the milk composition of primiparous and multiparous cows due to treatments.

There were no differences in percentage of $\mathrm{N}$ fractions in milk of primiparous and multiparous cows (Table 4). The yields of the various $\mathrm{N}$ fractions were not affected by treatment, with the exception of whey $\mathrm{N}$ yield, where a quadratic response $(P<0.01)$ occurred for primiparous cows. There was a tendency for a linear decrease in whey $\mathrm{N}$ percentage $(P<0.06)$ in multiparous cows.

Overall changes in the composition of individual FA of milk fat from primiparous cows were modest (Table $5)$. Content of $\mathrm{C} 18: 2$ tended $(P<0.10)$ to increase linearly as the proportion of $\mathrm{CrP}$ increased in the diet. In multiparous cows (Table 6), the proportion of $\mathrm{C} 12: 0$ ( $P$ $<0.08), \mathrm{C} 14: 0(P<0.02)$, and C16:0 $(P<0.07)$ decreased, or tended to decrease, and the proportion of C18:2 linearly increased $(P<0.01)$ with increasing proportion of $\mathrm{CrP}$ in the diet.

The FA composition of the milk fat globule membrane was substantially influenced by dietary treatments for primiparous cows with numerous changes occurring (Table 7). However, the conjugated linoleic acid (CLA) content of milk fat globule membrane did not differ. The proportion of C16:0 and C17:0 increased linearly $(P<0.05)$ and $\mathrm{C} 16: 1$ cis decreased linearly $(P<0.01)$ with increasing proportions of $\mathrm{CrP}$ in the diet. A similar pattern occurred in total milk FA for C16:0 and C17:0, although these changes were not significant. Content of C18:0 increased linearly $(P<0.01)$ with increasing proportion of $\mathrm{CrP}$ in the diets. The FA composition of the milk fat globule membrane from multiparous cows was not substantially influenced by dietary treatment (Table 8).

Plasma concentration of NEFA was different for time of sampling in primiparous cows, indicating that plasma NEFA concentrations were higher before feeding than at $2 \mathrm{~h}$ postfeeding (Table 9). In contrast, plasma concentration of NEFA was not different for time of sampling in multiparous cows. Plasma concentration of NEFA increased in plasma of multiparous cows with increasing proportion of CrP. Plasma glucose concentrations did not differ for primiparous and multiparous cows with increasing proportion of $\mathrm{CrP}$ in the diet. Plasma glucose was higher just before feeding compared to $2 \mathrm{~h}$ postfeeding for both primiparous and multiparous cows. Plasma urea $\mathrm{N}$ linearly decreased $(P<$ 0.02 ) in primiparous cows with increasing proportion of $\mathrm{CrP}$ in the diet. Plasma urea $\mathrm{N}$ did not differ with time of sampling for any parity group.

Total gossypol intake, as well as the intake of the (-) isomer, increased linearly $(P<0.01)$ with increasing proportions of $\mathrm{CrP}$ in the diet of both primiparous and multiparous cows (Table 10). The increased intake of gossypol reflected the higher content of gossypol in $\mathrm{CrP}$ compared with WCS (Table 1). The (-) isomer accounted for a larger part of the increment in TG intake than the $(+)$ isomer, as WCS was replaced by $\mathrm{CrP}$ in the diet, reflecting the higher proportion of the (-) isomer relative to the (+) isomer in $\mathrm{CrP}$ than in WCS (Table 1). Plasma concentrations of TG and the (-) isomer of 
Table 3. Dry matter intake, yield and composition of milk, and energy utilization for primiparous and multiparous cows fed diets varying in proportions of whole cottonseed (WCS) and cracked Pima cottonseed $(\mathrm{CrP})$.

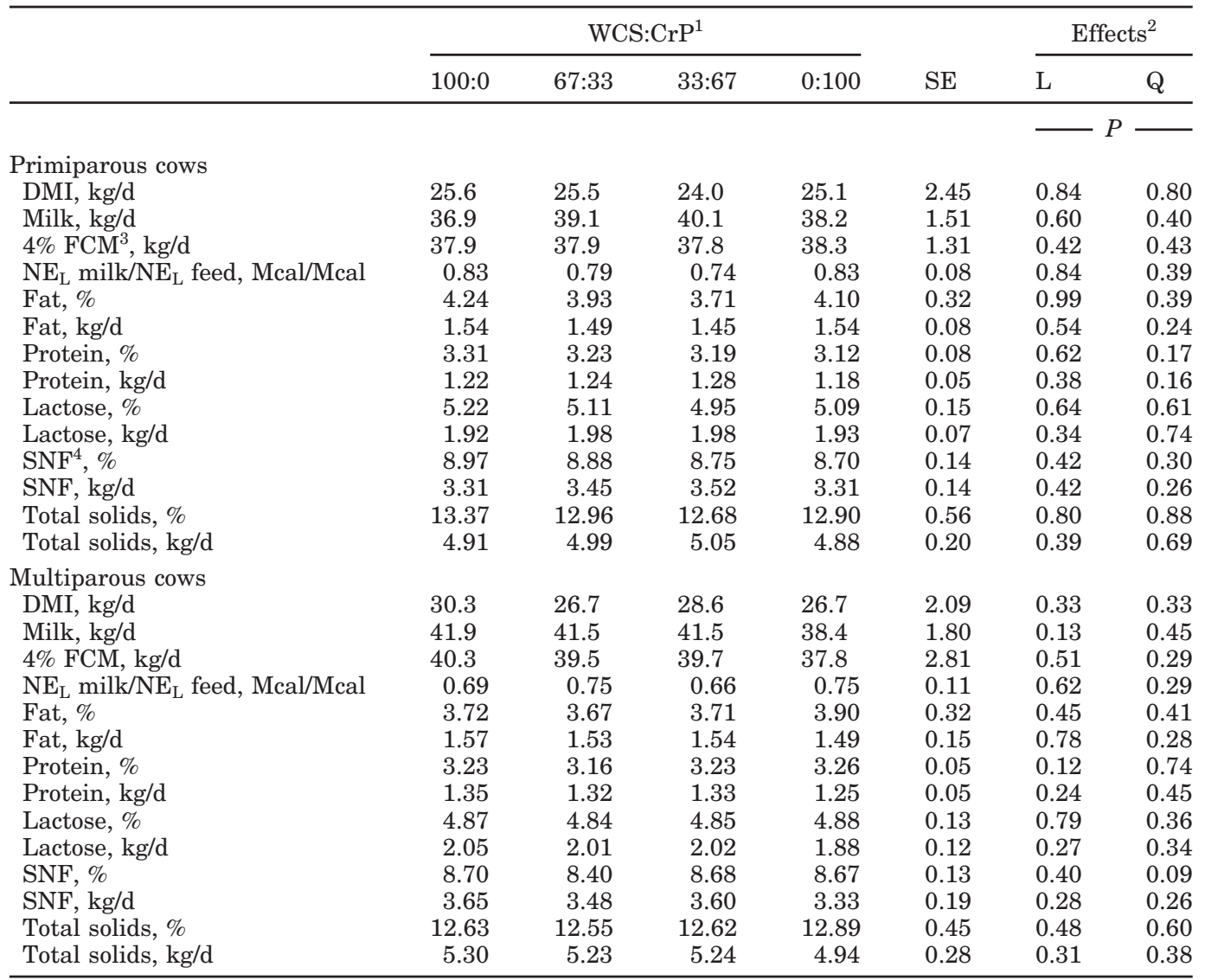

${ }^{1}$ WCS:CrP: Proportion of whole Upland cottonseed (WCS) to cracked Pima cottonseed (CrP).

${ }^{2} \mathrm{~L}=$ Linear effect; $\mathrm{Q}=$ quadratic effect.

${ }^{3} \mathrm{FCM}$, corrected at $4 \%$.

gossypol increased linearly with addition of $\mathrm{CrP}$ in the $\operatorname{diet}(P<0.01)$.

Erythrocyte fragility index, defined as the salt concentration at which 50\% hemolysis of red blood cells occurred, was not affected by diet (Table 10).

A similar response between plasma gossypol concentration and gossypol intake was observed in individual primiparous (Table 11). In contrast, plasma gossypol levels of individual multiparous cows responded differently $(P<0.01)$ to gossypol intake (Table 12$)$. This response was similar for TG, as well as for the (-) and (+) isomers of gossypol.

\section{DISCUSSION}

Although substantial data are available on the nutrient composition of WCS, little exists for Pima cottonseed. Sullivan et al. (1993a) reported higher levels of $\mathrm{CP}$ and ether extract, and lower levels of ADF and NDF, in WP compared with WCS. However, no data were reported for processed Pima. Although the composition of WP and processed Pima would likely be considered similar, this has not been demonstrated. In the present study, trends in composition of cottonseed were similar to the findings of Sullivan et al. (1993a), when comparing WCS and WP, although only the difference in ether extract was significant. Gossypol analysis of the cottonseeds used in this study showed similar trends to those reported by other authors comparing WCS and WP. While no data were found reporting gossypol values for CrP, several studies (Cass et al., 1991; Sullivan et al., 1993b; Calhoun et al., 1995a) reported similar values for TG, but higher concentrations of the (-) isomer in WP than in WCS.

Similar DMI among diets in both parities of cows is consistent with Sullivan et al. (1993a) and Sullivan et al. (1993b), who compared short staple cottonseed (SS) with $\mathrm{CrP}$ at $15 \%$ inclusion in the diet, where SS is equivalent to the whole fuzzy cottonseed used in the current study. Our results, together with those of Sulli- 
Table 4. Yield and content of $\mathrm{N}$ fractions in milk from primiparous and multiparous cows fed diets varying in proportions of whole cottonseed (WCS) and cracked Pima cottonseed (CrP).

\begin{tabular}{|c|c|c|c|c|c|c|c|}
\hline & \multicolumn{4}{|c|}{ WCS:CrP ${ }^{1}$} & \multirow[b]{2}{*}{$\mathrm{SE}$} & \multicolumn{2}{|c|}{ Effects $^{2}$} \\
\hline & 100:0 & $67: 33$ & $33: 67$ & $0: 100$ & & $\mathrm{~L}$ & $\mathrm{Q}$ \\
\hline & & & & & & $\longrightarrow$ & \\
\hline \multicolumn{8}{|c|}{ Primiparous cows } \\
\hline Total N, \% & 0.51 & 0.50 & 0.49 & 0.48 & 0.01 & 0.85 & 0.11 \\
\hline Total N, g/d & 188.7 & 193.6 & 199.0 & 184.6 & 6.22 & 0.38 & 0.16 \\
\hline Casein N, \% & 0.40 & 0.38 & 0.38 & 0.38 & $<0.01$ & 0.82 & 0.74 \\
\hline Casein $\mathrm{N}, \mathrm{g} / \mathrm{d}$ & 146.4 & 150.1 & 154.9 & 143.4 & 4.97 & 0.73 & 0.16 \\
\hline Whey N, \% & 0.08 & 0.08 & 0.08 & 0.08 & $<0.01$ & 0.47 & 0.11 \\
\hline Whey N, g/d & 30.6 & 31.8 & 32.1 & 29.5 & 1.18 & 0.26 & 0.01 \\
\hline NPN, \% & 0.03 & 0.03 & 0.03 & 0.03 & $<0.01$ & 0.23 & 0.38 \\
\hline NPN, g/d & 11.7 & 11.7 & 11.9 & 11.1 & 0.37 & 0.25 & 0.76 \\
\hline Urea N, mg/dl & 15.67 & 13.83 & 13.05 & 13.71 & 1.44 & 0.26 & 0.25 \\
\hline \multicolumn{8}{|c|}{ Multiparous cows } \\
\hline Total N, \% & 0.50 & 0.49 & 0.51 & 0.50 & 0.01 & 0.53 & 0.57 \\
\hline Total N, g/d & 211.1 & 204.8 & 210.2 & 192.0 & 8.79 & 0.24 & 0.45 \\
\hline Casein N, \% & 0.38 & 0.38 & 0.38 & 0.38 & $<0.01$ & 0.18 & 0.58 \\
\hline Casein N, g/d & 158.3 & 156.5 & 159.7 & 145.9 & 6.28 & 0.97 & 0.50 \\
\hline Whey N, \% & 41.5 & 37.5 & 38.7 & 36.1 & 2.29 & 0.06 & 0.43 \\
\hline Whey N, g/d & 0.10 & 0.09 & 0.09 & 0.09 & $<0.01$ & 0.19 & 0.32 \\
\hline NPN, $\%$ & 0.03 & 0.03 & 0.03 & 0.03 & $<0.01$ & 0.44 & 0.10 \\
\hline NPN, g/d & 11.3 & 10.8 & 11.7 & 10.0 & 0.73 & 0.34 & 0.09 \\
\hline Urea N, mg/dl & 12.53 & 11.78 & 14.18 & 12.08 & 0.44 & 0.33 & 0.05 \\
\hline
\end{tabular}

${ }^{1}$ WCS:CrP: Proportion of whole Upland cottonseed (WCS) to cracked Pima cottonseed (CrP).

${ }^{2} \mathrm{~L}=$ Linear effect; $\mathrm{Q}=$ quadratic effect.

Table 5. Fatty acid composition (g of FA/100 g of fat) of milk fat from primiparous cows.

\begin{tabular}{|c|c|c|c|c|c|c|c|}
\hline & \multicolumn{4}{|c|}{ WCS:CrP ${ }^{1}$} & \multirow[b]{2}{*}{$\mathrm{SE}$} & \multicolumn{2}{|c|}{ Effects $^{2}$} \\
\hline & $100: 0$ & $67: 33$ & $33: 67$ & $0: 100$ & & $\mathrm{~L}$ & Q \\
\hline & & & & & & $\longrightarrow$ & 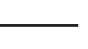 \\
\hline \multicolumn{8}{|l|}{ Fatty acid } \\
\hline $\mathrm{C} 4: 0$ & 4.10 & 4.08 & 4.02 & 4.25 & 0.18 & 0.78 & 0.33 \\
\hline C6:0 & 2.07 & 2.02 & 1.94 & 2.04 & 0.10 & 0.89 & 0.96 \\
\hline C8:0 & 1.09 & 1.01 & 0.98 & 1.00 & 0.06 & 0.51 & 0.62 \\
\hline C10:0 & 2.18 & 2.06 & 2.03 & 1.96 & 0.16 & 0.54 & 0.33 \\
\hline $\mathrm{C} 11: 0$ & 0.18 & 0.17 & 0.17 & 0.16 & 0.01 & 0.47 & 0.06 \\
\hline C12:0 & 2.40 & 2.24 & 2.25 & 2.12 & 0.17 & 0.39 & 0.31 \\
\hline C13:0 & 0.12 & 0.10 & 0.12 & 0.14 & 0.02 & 0.09 & 0.23 \\
\hline C14:0 & 8.76 & 8.77 & 8.89 & 8.30 & 0.40 & 0.46 & 0.15 \\
\hline $\mathrm{C} 14: 1 \mathrm{cis}$ & 0.67 & 0.62 & 0.68 & 0.58 & 0.02 & 0.08 & $<0.01$ \\
\hline C15:0 & 0.85 & 0.83 & 0.86 & 0.80 & 0.04 & 0.57 & 0.29 \\
\hline C16:0 & 28.82 & 28.49 & 29.32 & 29.25 & 0.79 & 0.34 & 0.85 \\
\hline $\mathrm{C} 16: 1$ trans & 0.35 & 0.33 & 0.35 & 0.32 & 0.03 & 0.15 & 0.55 \\
\hline $\mathrm{C} 16: 1 \mathrm{cis}$ & 1.21 & 1.26 & 1.32 & 1.23 & 0.06 & 0.18 & 0.12 \\
\hline $\mathrm{C} 17: 0$ & 0.62 & 0.64 & 0.64 & 0.67 & 0.03 & 0.28 & 0.80 \\
\hline C17:1 trans & 0.04 & 0.05 & 0.05 & 0.06 & 0.01 & 0.32 & 0.84 \\
\hline C18:0 & 18.01 & 17.90 & 15.84 & 17.77 & 0.65 & 0.15 & 0.09 \\
\hline $\mathrm{C} 18: 1 \mathrm{n} 9$ trans & 0.38 & 0.44 & 0.45 & 0.41 & 0.07 & 0.62 & 0.45 \\
\hline C18:1 n11 trans & 1.20 & 1.22 & 1.23 & 1.26 & 0.19 & 0.87 & 0.57 \\
\hline C18:1 & 23.64 & 24.27 & 24.96 & 23.98 & 0.97 & 0.73 & 0.70 \\
\hline C18:2 & 2.36 & 2.56 & 2.82 & 2.77 & 0.15 & 0.10 & 0.96 \\
\hline C18:3 & 0.51 & 0.51 & 0.60 & 0.54 & 0.02 & 0.14 & 0.84 \\
\hline $\mathrm{CLA}^{3}$ & 0.43 & 0.45 & 0.51 & 0.42 & 0.04 & 0.96 & 0.27 \\
\hline
\end{tabular}

${ }^{1}$ WCS:CrP: Proportion of whole Upland cottonseed (WCS) to cracked Pima cottonseed (CrP).

${ }^{2} \mathrm{~L}=$ Linear effect; $\mathrm{Q}=$ quadratic effect.

${ }^{3}$ CLA: Conjugated linoleic acid. 
Table 6. Fatty acid composition (g of FA/100 $\mathrm{g}$ of fat) of milk fat from multiparous cows.

\begin{tabular}{|c|c|c|c|c|c|c|c|}
\hline & \multicolumn{4}{|c|}{ WCS:CrP ${ }^{1}$} & \multirow[b]{2}{*}{ SE } & \multicolumn{2}{|c|}{ Effects $^{2}$} \\
\hline & 100:0 & $67: 33$ & $33: 67$ & $0: 100$ & & $\mathrm{~L}$ & $\mathrm{Q}$ \\
\hline & & & & & & $\longrightarrow$ & 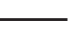 \\
\hline \multicolumn{8}{|l|}{ Fatty acid } \\
\hline $\mathrm{C} 4: 0$ & 4.04 & 4.36 & 4.27 & 4.02 & 0.12 & 0.36 & 0.54 \\
\hline C6:0 & 2.13 & 2.16 & 2.23 & 2.01 & 0.07 & 0.06 & 0.50 \\
\hline $\mathrm{C} 8: 0$ & 1.11 & 1.07 & 1.14 & 1.01 & 0.05 & 0.07 & 0.90 \\
\hline C10:0 & 2.28 & 2.14 & 2.32 & 2.00 & 0.14 & 0.10 & 0.86 \\
\hline C11:0 & 0.19 & 0.18 & 0.19 & 0.17 & 0.01 & 0.04 & 0.87 \\
\hline C12:0 & 2.48 & 2.28 & 2.44 & 2.17 & 0.14 & 0.08 & 0.92 \\
\hline C13:0 & 0.13 & 0.11 & 0.12 & 0.10 & 0.02 & 0.08 & 0.43 \\
\hline C14:0 & 9.47 & 8.99 & 9.05 & 8.38 & 0.32 & 0.02 & 0.99 \\
\hline C14:1 trans & 0.01 & 0.01 & 0.01 & $<0.01$ & $<0.01$ & 0.32 & 0.65 \\
\hline $\mathrm{C} 14: 1 \mathrm{cis}$ & 0.77 & 0.69 & 0.66 & 0.65 & 0.10 & 0.14 & 0.74 \\
\hline C15:0 & 0.91 & 0.84 & 0.84 & 0.81 & 0.03 & 0.04 & 0.85 \\
\hline C16:0 & 28.92 & 28.27 & 28.01 & 27.59 & 0.47 & 0.07 & 0.69 \\
\hline C16:1 trans & 0.35 & 0.32 & 0.32 & 0.32 & 0.02 & 0.20 & 0.71 \\
\hline $\mathrm{C} 16: 1 \mathrm{cis}$ & 1.50 & 1.27 & 1.28 & 1.36 & 0.19 & 0.84 & 0.60 \\
\hline C17:0 & 0.60 & 0.62 & 0.64 & 0.66 & 0.02 & 0.01 & 0.75 \\
\hline $\mathrm{C} 17: 1$ trans & 0.05 & 0.04 & 0.04 & 0.05 & 0.01 & 0.66 & 0.44 \\
\hline C18:0 & 16.32 & 17.48 & 17.89 & 18.12 & 0.89 & 0.11 & 0.92 \\
\hline $\mathrm{C} 18: 1 \mathrm{n} 9$ trans & 0.41 & 0.43 & 0.41 & 0.41 & 0.04 & 0.71 & 0.62 \\
\hline C18:1 n11 trans & 1.37 & 1.35 & 1.21 & 1.32 & 0.07 & 0.17 & 0.14 \\
\hline C18:1 & 23.29 & 23.53 & 22.95 & 24.42 & 1.12 & 0.37 & 0.93 \\
\hline C18:2 & 2.61 & 2.85 & 3.03 & 3.38 & 0.15 & $<0.01$ & 0.51 \\
\hline C18:3 & 0.57 & 0.54 & 0.59 & 0.61 & 0.05 & 0.45 & 0.96 \\
\hline $\mathrm{CLA}^{3}$ & 0.53 & 0.48 & 0.41 & 0.48 & 0.05 & 0.23 & 0.39 \\
\hline
\end{tabular}

${ }^{1}$ WCS:CrP: Proportion of whole Upland cottonseed (WCS) to cracked Pima cottonseed (CrP).

${ }^{2} \mathrm{~L}=$ Linear effect; $\mathrm{Q}=$ quadratic effect.

${ }^{3}$ CLA: Conjugated linoleic acid.

Table 7. Fatty acid composition of milk fat globule membrane (g of FA/100 g of fatty acid) from primiparous cows.

\begin{tabular}{|c|c|c|c|c|c|c|c|}
\hline & \multicolumn{4}{|c|}{ WCS:CrP ${ }^{1}$} & \multirow[b]{2}{*}{$\mathrm{SE}$} & \multicolumn{2}{|c|}{ Effects $^{2}$} \\
\hline & $100: 0$ & $67: 33$ & $33: 67$ & $0: 100$ & & $\mathrm{~L}$ & $\mathrm{Q}$ \\
\hline & & & & & & 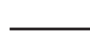 & 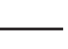 \\
\hline \multicolumn{8}{|l|}{ Fatty acid } \\
\hline $\mathrm{C} 4: 0$ & 0.75 & 0.91 & 0.67 & 0.80 & 0.10 & 0.15 & 0.43 \\
\hline C6:0 & 0.53 & 0.64 & 0.44 & 0.49 & 0.08 & 0.05 & 0.69 \\
\hline $\mathrm{C} 8: 0$ & 0.40 & 0.46 & 0.35 & 0.37 & 0.04 & 0.08 & 0.29 \\
\hline C10:0 & 1.02 & 1.19 & 0.92 & 0.92 & 0.14 & 0.14 & 0.20 \\
\hline $\mathrm{C} 12: 0$ & 1.33 & 1.46 & 1.24 & 1.26 & 0.16 & 0.39 & 0.40 \\
\hline C14:0 & 5.44 & 6.24 & 5.45 & 6.14 & 0.75 & 0.62 & 0.96 \\
\hline $\mathrm{C} 15: 0$ & 0.62 & 0.69 & 0.70 & 0.66 & 0.08 & 0.60 & 0.42 \\
\hline $\mathrm{C} 16: 0$ & 22.62 & 24.55 & 23.71 & 28.01 & 2.27 & 0.05 & 0.35 \\
\hline C16:1 trans & 0.24 & 0.25 & 0.29 & 0.26 & 0.04 & 0.70 & 0.62 \\
\hline $\mathrm{C} 16: 1 \mathrm{cis}$ & 1.23 & 1.18 & 1.12 & 0.96 & 0.07 & 0.01 & 0.15 \\
\hline C17:0 & 0.52 & 0.57 & 0.56 & 0.67 & 0.05 & 0.04 & 0.27 \\
\hline C18:0 & 18.01 & 19.63 & 18.23 & 21.60 & 0.32 & $<0.01$ & 0.04 \\
\hline C18:1 n9 trans & 0.55 & 0.56 & 0.58 & 0.54 & 0.03 & 0.70 & 0.40 \\
\hline C18:1 n11 trans & 1.01 & 1.09 & 1.04 & 0.98 & 0.11 & 0.46 & 0.44 \\
\hline C18:1 & 33.69 & 29.99 & 32.04 & 26.99 & 2.55 & 0.04 & 0.55 \\
\hline C18:2 & 9.33 & 8.19 & 10.04 & 7.94 & 0.80 & 0.21 & 0.39 \\
\hline C18:3 & 0.82 & 0.74 & 0.86 & 0.66 & 0.04 & 0.01 & 0.17 \\
\hline $\mathrm{CLA}^{3}$ & 0.56 & 0.58 & 0.62 & 0.45 & 0.03 & 0.25 & 0.37 \\
\hline
\end{tabular}

${ }^{1}$ WCS:CrP: Proportion of whole Upland cottonseed (WCS) to cracked Pima cottonseed (CrP).

${ }^{2} \mathrm{~L}=$ Linear effect; $\mathrm{Q}=$ quadratic effect.

${ }^{3}$ CLA: Conjugated linoleic acid. 
Table 8. Fatty acid composition of milk fat globule membrane (g of FA/100 g of fatty acid) from multiparous cows.

\begin{tabular}{|c|c|c|c|c|c|c|c|}
\hline & \multicolumn{4}{|c|}{ WCS:CrP ${ }^{1}$} & \multirow[b]{2}{*}{ SE } & \multicolumn{2}{|c|}{ Effects $^{2}$} \\
\hline & $100: 0$ & $67: 33$ & $33: 67$ & $0: 100$ & & $\mathrm{~L}$ & $\mathrm{Q}$ \\
\hline & & & & & & $\longrightarrow$ & - \\
\hline \multicolumn{8}{|l|}{ Fatty acid } \\
\hline $\mathrm{C} 4: 0$ & 0.64 & 0.66 & 0.59 & 0.66 & 0.11 & 0.74 & 0.08 \\
\hline C6:0 & 0.54 & 0.58 & 0.64 & 0.44 & 0.16 & 0.58 & 0.56 \\
\hline $\mathrm{C} 8: 0$ & 0.38 & 0.41 & 0.43 & 0.33 & 0.13 & 0.63 & 0.88 \\
\hline C10:0 & 0.99 & 0.93 & 1.03 & 0.80 & 0.23 & 0.44 & 0.98 \\
\hline C12:0 & 1.34 & 1.24 & 1.31 & 1.03 & 0.24 & 0.19 & 0.99 \\
\hline C14:0 & 6.41 & 5.70 & 6.07 & 5.29 & 0.79 & 0.22 & 0.80 \\
\hline C15:0 & 0.77 & 0.65 & 0.68 & 0.65 & 0.10 & 0.40 & 0.57 \\
\hline C16:0 & 26.57 & 24.17 & 25.74 & 24.56 & 2.20 & 0.78 & 0.68 \\
\hline $\mathrm{C} 16: 1$ trans & 0.28 & 0.22 & 0.26 & 0.22 & 0.03 & 0.20 & 0.60 \\
\hline $\mathrm{C} 16: 1 \mathrm{cis}$ & 1.30 & 1.06 & 1.03 & 1.06 & 0.20 & 0.32 & 0.71 \\
\hline C17:0 & 0.58 & 0.55 & 0.64 & 0.58 & 0.05 & 0.23 & 0.39 \\
\hline C18:0 & 19.58 & 20.70 & 22.19 & 20.90 & 1.72 & 0.25 & 0.68 \\
\hline $\mathrm{C} 18: 1 \mathrm{n} 9$ trans & 0.53 & 0.57 & 0.52 & 0.55 & 0.04 & 0.49 & 0.44 \\
\hline $\mathrm{C} 18: 1 \mathrm{n} 11$ trans & 1.07 & 0.99 & 1.01 & 1.06 & 0.04 & 0.46 & 0.02 \\
\hline C18:1 & 27.72 & 28.85 & 26.54 & 27.90 & 2.35 & 0.63 & 0.72 \\
\hline C18:2 & 8.74 & 10.08 & 8.89 & 11.35 & 2.09 & 0.42 & 0.92 \\
\hline C18:3 & 0.75 & 0.78 & 0.78 & 0.81 & 0.15 & 0.99 & 0.76 \\
\hline CLA $^{3}$ & 0.62 & 0.54 & 0.45 & 0.52 & 0.03 & 0.11 & 0.40 \\
\hline
\end{tabular}

${ }^{1}$ WCS:CrP: Proportion of whole Upland cottonseed (WCS) to cracked Pima cottonseed (CrP).

${ }^{2} \mathrm{~L}=$ Linear effect; $\mathrm{Q}=$ quadratic effect.

${ }^{3}$ CLA: Conjugated linoleic acid.

van et al. (1993a) and (1993b), indicate that $\mathrm{CrP}$ can be fed up to $12.8 \%$ of the diet DM for up to $35 \mathrm{~d}$ with little effect on the DMI of both primiparous and multiparous cows.

Similar yield and composition of milk from primiparous and multiparous cows (Table 3) among diets is consistent with Brown et al. (1982), who fed diets containing either SS, WP, or CrP to multiparous cows and for cows fed diets containing either SS or WP (Kiesling and Miller, 1985). Sullivan et al. (1993a) reported higher milk yields in cows fed diets containing ground Pima than with WP and CrP, indicating that type of processing impacted utilization of Pima cottonseed. However, milk yield of cows did not differ when diets contained ground Pima compared with SS. In a subsequent study, Sullivan et al. (1993b) found no differences in yields of milk and 3.5\% FCM by cows fed diets containing either SS, WCS, WP, or CrP. No information on milk production responses of primiparous cows fed different varieties of cottonseed was found in the literature. Overall, the available information for multiparous cows indicates that the milk production response to cottonseed variety and method of processing is highly variable and depends on the amount of cottonseed included in the diet as well as the period of time that cottonseed is fed. Our findings indicate that $\mathrm{CrP}$ can be fed at up to $12.8 \%$ of diet DM for 35 d without affecting milk production of primiparous and multiparous cows.
No dietary differences were detected for milk fat and protein percentages, as well as yields, in both parities of cows (Table 3). Previous studies (Brown et al., 1982; Kiesling and Miller, 1985; Sullivan et al., 1993a) also found no difference in milk fat and protein content in response to feeding whole or $\mathrm{CrP}$ in multiparous cows. In contrast, Sullivan et al. (1993b) reported an increase in milk fat percent when cows were fed $\mathrm{CrP}$ or WP compared with WCS instead of SS, but there were no differences in milk fat yield. Content and yield of lactose and SNF did not differ among treatments, consistent with Sullivan et al. (1993b) and Brown et al. (1982).

Yield of the various milk $\mathrm{N}$ fractions of primiparous and multiparous cows was not affected by treatment, consistent with DePeters and Cant (1992), except for the whey $\mathrm{N}$ yield, which had a quadratic response in primiparous cows and tended to linearly decrease in multiparous cows. Similar concentrations of MUN among diets were expected based on previous reports (DePeters and Ferguson, 1992).

Although responses in the FA composition of milk fat differed between primiparous and multiparous cows, some FA tended to behave in a similar fashion (Tables 5 and 6). The higher proportion of C18:2 in the milk of both parities of cows, with increasing proportions of $\mathrm{CrP}$ in the diet, could be a consequence of a higher rate of ruminal passage of $\mathrm{CrP}$ compared with WCS, thereby decreasing the efficiency of biohydrogenation in the rumen and increasing the proportion of $\mathrm{C} 18: 2$ leaving the 
Table 9. Concentrations of plasma constituents for primiparous and multiparous cows.

\begin{tabular}{|c|c|c|c|c|c|c|c|c|}
\hline & \multicolumn{4}{|c|}{ WCS:CrP ${ }^{1}$} & \multirow[b]{2}{*}{ SE } & \multicolumn{3}{|c|}{ Effects $^{2}$} \\
\hline & 100:0 & $67: 33$ & $33: 67$ & $0: 100$ & & Hour & $\mathrm{L}$ & $\mathrm{Q}$ \\
\hline & & & & & & 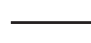 & $P$ & - \\
\hline \multicolumn{9}{|c|}{$\begin{array}{l}\text { Primiparous cows } \\
\text { NEFA, } \mu M\end{array}$} \\
\hline $0 \mathrm{~h}$ & 259.9 & 353.3 & 268.9 & 219.0 & 71.26 & 0.05 & 0.09 & 0.17 \\
\hline $2 \mathrm{~h}$ & 187.3 & 249.6 & 158.0 & 183.2 & & & & \\
\hline \multicolumn{9}{|c|}{ Glucose, mg/dl } \\
\hline $0 \mathrm{~h}$ & 74.2 & 74.4 & 74.7 & 73.9 & 1.55 & $<0.01$ & 0.90 & 0.80 \\
\hline $2 \mathrm{~h}$ & 70.7 & 70.3 & 72.0 & 72.4 & & & & \\
\hline \multicolumn{9}{|c|}{$\mathrm{PUN}^{3}, \mathrm{mg} / \mathrm{dl}$} \\
\hline $0 \mathrm{~h}$ & 16.0 & 14.3 & 13.4 & 13.8 & 1.13 & 0.40 & 0.02 & 0.22 \\
\hline $2 \mathrm{~h}$ & 16.9 & 15.2 & 14.3 & 14.3 & & & & \\
\hline \multicolumn{9}{|c|}{ Multiparous cows } \\
\hline \multicolumn{9}{|c|}{ NEFA, $\mu M$} \\
\hline $0 \mathrm{~h}$ & 193.7 & 186.0 & 222.3 & 239.5 & 56.68 & 0.16 & 0.04 & 0.98 \\
\hline $2 \mathrm{~h}$ & 154.5 & 155.4 & 192.7 & 193.2 & & & & \\
\hline \multicolumn{9}{|c|}{ Glucose, $\mathrm{mg} / \mathrm{dl}$} \\
\hline $0 \mathrm{~h}$ & 75.0 & 74.7 & 73.4 & 74.0 & 2.89 & 0.01 & 0.39 & 0.67 \\
\hline $2 \mathrm{~h}$ & 71.1 & 70.2 & 70.4 & 69.9 & & & & \\
\hline \multicolumn{9}{|c|}{ PUN, mg/dl } \\
\hline $0 \mathrm{~h}$ & 14.4 & 12.8 & 15.2 & 12.7 & 1.62 & 0.48 & 0.78 & 0.27 \\
\hline $2 \mathrm{~h}$ & 14.7 & 13.7 & 15.8 & 14.1 & & & & \\
\hline
\end{tabular}

${ }^{1}$ WCS:CrP: Proportion of whole Upland cottonseed (WCS) to cracked Pima cottonseed (CrP).

${ }^{2}$ Hour $=P<0.05$ indicate significant difference between sampling time; $\mathrm{L}=$ linear effect; $\mathrm{Q}=$ quadratic effect.

${ }^{3}$ PUN: Plasma urea nitrogen.

rumen. Potentially higher mastication during rumination of WCS may produce a slower ruminal release of the cottonseed oil than in $\mathrm{CrP}$, thus allowing for more complete hydrogenation of unsaturated FA. Alterna- tively, the oil in $\mathrm{CrP}$ may be more readily available to microbial enzymes in the rumen, although the finer particle size may result in more passage of oils containing unsaturated FA from the rumen. The trans-11

Table 10. Gossypol intake, plasma gossypol concentration, and erythrocyte fragility (EF) index ${ }^{1}$ of primiparous and multiparous cows.

\begin{tabular}{|c|c|c|c|c|c|c|c|}
\hline & \multicolumn{4}{|c|}{ WCS:CrP ${ }^{2}$} & \multirow[b]{2}{*}{ SE } & \multicolumn{2}{|c|}{ Effects $^{3}$} \\
\hline & 100:0 & $67: 33$ & $33: 67$ & $0: 100$ & & $\mathrm{~L}$ & $\mathrm{Q}$ \\
\hline & & & & & & $\longrightarrow$ & 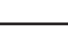 \\
\hline \multicolumn{8}{|l|}{ Primiparous cows } \\
\hline \multicolumn{8}{|l|}{ Total gossypol } \\
\hline Intake, g/d & 20.9 & 24.9 & 27.4 & 32.7 & 2.86 & $<0.01$ & 0.84 \\
\hline Plasma, $\mu \mathrm{g} / \mathrm{ml}$ & 4.4 & 6.0 & 7.7 & 8.9 & 0.90 & $<0.01$ & 0.56 \\
\hline \multicolumn{8}{|c|}{ Negative gossypol } \\
\hline Intake, g/d & 8.7 & 11.5 & 13.5 & 17.0 & 1.43 & $<0.01$ & 0.85 \\
\hline Plasma, $\mu \mathrm{g} / \mathrm{ml}$ & 2.8 & 3.9 & 5.1 & 5.9 & 0.60 & $<0.01$ & 0.54 \\
\hline EF Index ${ }^{1}$ & 0.518 & 0.518 & 0.525 & 0.543 & 0.02 & 0.31 & 0.23 \\
\hline \multicolumn{8}{|l|}{ Multiparous cows } \\
\hline \multicolumn{8}{|l|}{ Total gossypol } \\
\hline Intake, $\mathrm{g} / \mathrm{d}$ & 24.7 & 26.2 & 32.6 & 34.8 & 2.73 & $<0.01$ & 0.53 \\
\hline Plasma, $\mu \mathrm{g} / \mathrm{ml}$ & 4.3 & 7.3 & 9.7 & 11.4 & 0.84 & $<0.01$ & 0.12 \\
\hline \multicolumn{8}{|l|}{ Negative gossypol } \\
\hline Intake, $\mathrm{g} / \mathrm{d}$ & 10.3 & 12.1 & 13.1 & 18.0 & 1.42 & $<0.01$ & 0.62 \\
\hline Plasma, $\mu \mathrm{g} / \mathrm{ml}$ & 2.6 & 4.8 & 6.3 & 7.4 & 0.62 & $<0.01$ & 0.14 \\
\hline EF Index ${ }^{1}$ & 0.516 & 0.534 & 0.538 & 0.543 & 0.02 & 0.31 & 0.92 \\
\hline
\end{tabular}


Table 11. Regression analysis of plasma gossypol ( $\mu \mathrm{g} / \mathrm{ml})$ on gossypol intake $(\mathrm{g} / \mathrm{d})$ in primiparous cows.

\begin{tabular}{|c|c|c|c|c|c|c|c|}
\hline & \multirow[b]{2}{*}{ Slope } & \multirow[b]{2}{*}{$\mathrm{SE}$} & \multirow[b]{2}{*}{$\mathrm{P}$} & \multicolumn{4}{|c|}{ Contrast $^{1}$} \\
\hline & & & & $\begin{array}{l}\text { Animal } \\
1\end{array}$ & $\begin{array}{l}\text { Animal } \\
2\end{array}$ & $\begin{array}{l}\text { Animal } \\
3\end{array}$ & $\begin{array}{l}\text { Animal } \\
4\end{array}$ \\
\hline \multicolumn{8}{|c|}{ Total gossypol } \\
\hline Animal 1 & 0.30 & 0.04 & $<0.01$ & & 0.48 & 0.31 & 0.29 \\
\hline Animal 2 & 0.26 & 0.04 & $<0.01$ & 0.48 & & 0.72 & 0.68 \\
\hline Animal 3 & 0.24 & 0.04 & $<0.01$ & 0.31 & 0.72 & & 0.96 \\
\hline Animal 4 & 0.24 & 0.04 & $<0.01$ & 0.29 & 0.68 & 0.96 & \\
\hline \multicolumn{8}{|c|}{ Negative gossypol } \\
\hline Animal 1 & 0.41 & 0.05 & $<0.01$ & & 0.34 & 0.28 & 0.18 \\
\hline Animal 2 & 0.34 & 0.04 & $<0.01$ & 0.34 & & 0.86 & 0.64 \\
\hline Animal 3 & 0.33 & 0.05 & $<0.01$ & 0.28 & 0.86 & & 0.78 \\
\hline Animal 4 & 0.31 & 0.05 & $<0.01$ & 0.18 & 0.64 & 0.78 & \\
\hline \multicolumn{8}{|c|}{ Positive gossypol } \\
\hline Animal 1 & 0.20 & 0.03 & $<0.01$ & & 0.65 & 0.31 & 0.43 \\
\hline Animal 2 & 0.18 & 0.03 & $<0.01$ & 0.65 & & 0.53 & 0.70 \\
\hline Animal 3 & 0.15 & 0.03 & $<0.01$ & 0.31 & 0.53 & & 0.81 \\
\hline Animal 4 & 0.16 & 0.03 & $<0.01$ & 0.43 & 0.70 & 0.81 & \\
\hline
\end{tabular}

${ }^{1}$ Contrast $=P<0.05$ indicate significant difference between slopes.

C18:1 content of milk fat did not vary with treatment, which could indicate that biohydrogenation in the rumen was similar. Trans-11 C18:1 is an intermediate in biohydrogenation (Harfoot, 1978), and the lack of difference due to diet suggests that even though the oil in $\mathrm{CrP}$ is likely more readily available to microbial enzymes, due to the small particle size, the level of $\mathrm{CrP}$ feeding in the current study was perhaps not high enough to affect ruminal biohydrogenation of unsaturated FA.

The FA composition of the milk fat globule membrane (Tables 7 and 8) was measured to determine whether specific FA, particularly CLA, were higher in the membranes. The CLA have been reported to possess poten- tially beneficial health benefits (anticarcinogenic) for humans (Parodi, 1999), in particular the cis-9, trans11 isomer of C18:2. However, no difference in CLA was found in the composition of the milk fat globule membrane of primiparous and multiparous cows.

Because intake of fat did not differ among treatments, a change in plasma NEFA concentration would not be expected unless cows were in different states of adipose tissue mobilization, which was not the case in the present study. There is not an evident explanation for the changes observed on plasma NEFA concentrations with increasing proportion of $\mathrm{CrP}$ in the diet of both parities of cows. Elevated plasma lipids have been observed with increased absorption of supplemental dietary fat

Table 12. Regression analysis of plasma gossypol ( $\mu \mathrm{g} / \mathrm{ml})$ on gossypol intake $(\mathrm{g} / \mathrm{d})$ in multiparous cows.

\begin{tabular}{|c|c|c|c|c|c|c|}
\hline & \multirow[b]{2}{*}{ Slope } & \multirow[b]{2}{*}{$\mathrm{SE}$} & \multirow[b]{2}{*}{$\mathrm{P}$} & \multicolumn{3}{|c|}{ Contrast $^{1}$} \\
\hline & & & & $\begin{array}{l}\text { Animal } \\
1\end{array}$ & $\begin{array}{l}\text { Animal } \\
2\end{array}$ & $\begin{array}{l}\text { Animal } \\
3\end{array}$ \\
\hline & & & & 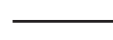 & $-P$ & - \\
\hline \multicolumn{7}{|c|}{ Total gossypol } \\
\hline Animal 1 & 0.26 & 0.03 & $<0.01$ & & $<0.01$ & $<0.01$ \\
\hline Animal 2 & 0.14 & 0.03 & $<0.01$ & $<0.01$ & & $<0.01$ \\
\hline Animal 3 & 0.45 & 0.03 & $<0.01$ & $<0.01$ & $<0.01$ & \\
\hline \multicolumn{7}{|c|}{ Negative gossypol } \\
\hline Animal 1 & 0.36 & 0.03 & $<0.01$ & & $<0.01$ & $<0.01$ \\
\hline Animal 2 & 0.19 & 0.03 & $<0.01$ & $<0.01$ & & $<0.01$ \\
\hline Animal 3 & 0.60 & 0.04 & $<0.01$ & $<0.01$ & $<0.01$ & \\
\hline \multicolumn{7}{|c|}{ Positive gossypol } \\
\hline Animal 1 & 0.18 & 0.02 & $<0.01$ & & 0.04 & $<0.01$ \\
\hline Animal 2 & 0.10 & 0.02 & $<0.01$ & 0.04 & & $<0.01$ \\
\hline Animal 3 & 0.31 & 0.03 & $<0.01$ & $<0.01$ & $<0.01$ & \\
\hline
\end{tabular}

${ }^{1}$ Contrast $=P<0.05$ indicate significant difference between slopes. 
(Cant et al., 1993; Avila et al., 2000); however, the intake of ether extract did not vary in the present study. The changes observed in plasma urea nitrogen (PUN) (Table 9) in response to diet reflected the changes observed in milk urea nitrogen (Table 4). A decrease in PUN concentration might be an indicator of gossypol intoxication due to damage of liver cells and, thus, diminished capability of the liver to synthesize urea (Barraza et al., 1991). The decrease in PUN concentration when the proportion of $\mathrm{CrP}$ was increased in the diet of primiparous cows could indicate a possible effect of gossypol on liver metabolism. However, since liver enzymes were not studied in the present research, it is difficult to conclude that liver cells were negatively affected by gossypol based solely on the decrease in PUN concentration that was observed as numerous dietary factors are known to affect PUN concentrations.

Most plasma TG concentrations were well above the proposed safe upper limit of $5 \mu \mathrm{g} / \mathrm{ml}$ (Calhoun et al., 1995a). Only when cows consumed the diet containing $100 \%$ WCS were plasma TG concentrations consistently below $5 \mu \mathrm{g} / \mathrm{ml}$ for both parities of cows. Although plasma gossypol concentrations were consistently well above the proposed upper safe limit when $\mathrm{CrP}$ was included in the diet, no symptoms of gossypol toxicity such as decreased feed intake or milk production were observed. Gossypol poisoning has been suspected in some commercial herds in the southwest United States where plasma gossypol concentrations above $10 \mu \mathrm{g} / \mathrm{ml}$ were reported (Calhoun et al., 1995a). The lack of symptoms of gossypol toxicity suggests that plasma TG concentration alone may not be an adequate indicator to determine safe levels of cotton byproducts in diets, at least when cotton byproducts are fed for relatively short periods of time.

Noftsger et al. (2000) reported decreased plasma TG levels when the level of expanded-expelled whole cottonseed was reduced from 28 to $14 \%$ of DM in diets of primiparous and multiparous Holstein dairy cows. In the same study, a diet containing $14 \%$ whole cottonseed yielded similar plasma gossypol levels to a diet with $14 \%$ expanded-expelled whole cottonseed. These findings indicate that gossypol availability in the digestive tract is highly dependent on cottonseed type and processing method, as suggested by Calhoun et al. (1995b). The linear increase in plasma TG concentrations with increasing proportions of $\mathrm{CrP}$ in the diets could be partly due to higher gossypol intakes but, because the slopes substantially exceed 1 , also by the possibility of a higher rate of ruminal passage of CrP than WCS from the rumen due to the smaller particle size of $\mathrm{CrP}$, which could

\footnotetext{
${ }^{1,2}$ Figures 1 and 2 were inadvertently omitted but can be viewed herein on page 406 .
}

have reduced the time available to detoxify the seed in the rumen. In the whole seed, gossypol is found in discrete glands. Calhoun et al. (1995a) also proposed that cracking or grinding of the whole seed disrupts some of these glands resulting in release of some gossypol, which could bind to other feed particles before feeding, and this binding could reduce rumen detoxification.

Erythrocyte fragility was proposed as a sensitive indicator of systemic gossypol status because it increased shortly after gossypol consumption was initiated (Velasquez-Pereira et al., 1998). The mechanism by which gossypol affects erythrocyte fragility is not known, although it has been speculated that gossypol may interact directly with the red blood cell membrane (Harvey, 1989; Calhoun et al., 1990). More recently, Velasquez-Pereira et al. (1988) suggested that the presence of gossypol in a lipid bilayer, such as the erythrocyte membrane, would alter membrane fluidity and, this may explain the increased fragility. Consistent with our findings, Hawkins (1985) did not observe an increase in the erythrocyte fragility index when both primiparous and multiparous Holstein cows were supplemented with WCS at up to $18.5 \%$ of the diet DM. Similarly, Coppock et al. (1985) reported no differences in the fragility of erythrocytes of primiparous and multiparous lactating Holstein cows when the level of WCS was increased from 0 to $30 \%$ of the diet. In contrast, others (Lindsey et al., 1980; Gray et al., 1993; Risco et al., 1993; Willard et al., 1995; Velasquez-Pereira et al., 1998) reported an increase in erythrocyte fragility with increasing levels of cottonseed byproducts in the diet. In many of the studies that have demonstrated an effect of gossypol intake on erythrocyte fragility, cottonseed meal was the main source of gossypol in the diet. Noftsger et al. (2000) proposed that the amount of gossypol absorbed is related to the concentration of both free and bound gossypol in cotton byproducts and their availability. The frequently higher level of gossypol, and the higher rates of ruminal passage of cottonseed meal compared with WCS, could explain part of the differences in erythrocyte fragility responses.

The similar response observed in plasma gossypol concentration to gossypol intake among individual primiparous cows (Figure 1A) ${ }^{1}$ indicates that the mechanism by which gossypol was detoxified was similar among cows. In addition, the C18:2 content in milk fat did not differ among treatments in primiparous cows, possibly indicating similar rates of passage from the rumen. If the rate of passage of cottonseed was increased, it is possible that some C18:2 might have escaped ruminal biohydrogenation, and this would be reflected by an increase in the C18:2 in the milk fat. However, the lack of a relationship between C18:2 in milk fat and plasma gossypol concentration (Figure $2 \mathrm{~A})^{2}$ casts doubt on this possibility. 
In contrast to primiparous cows, the plasma gossypol concentration in response to gossypol intake differed among individual multiparous cows (Figure 1B). The C18:2 content of milk fat also varied among the multiparous cows and a higher C18:2 in milk fat was associated with a higher plasma gossypol (Figure $2 \mathrm{~B}$ ). If the rate of passage of cottonseed was higher in one multiparous cow than another, an event commonly observed in our laboratory, more C18:2 might escape ruminal biohydrogenation concomitant with more gossypol leaving the rumen as free gossypol rather than bound gossypol, so resulting in an increase in C18:2 in milk fat and a simultaneous increase in blood plasma gossypol.

\section{CONCLUSIONS}

Total plasma gossypol concentrations increased linearly with increasing proportions of $\mathrm{CrP}$ in the diet for both primiparous and multiparous cows. While individual primiparous cows responded similarly to gossypol intake, the response of plasma gossypol to gossypol intake in individual multiparous cows differed among cows. This suggests that while both the amount of gossypol fed, and its intestinal availability, are important in determining plasma gossypol concentrations, differences among individuals must be considered when relating plasma gossypol levels with gossypol intake. The lack of symptoms of gossypol toxicity in this study, in spite of plasma gossypol concentrations well above the proposed safe upper limit of $5 \mu \mathrm{g} / \mathrm{ml}$, suggests that plasma gossypol concentration alone may be an adequate measure to determine safe levels of cotton byproducts in diets.

Nutrient intake, milk yield, milk composition, and efficiency of use of $\mathrm{NE}_{\mathrm{L}}$ were clearly not affected when WCS was replaced by increasing proportions of $\mathrm{CrP}$ in the ration up to $8.6 \%$ of diet DM, even though plasma gossypol levels increased substantially over this range. Although the highest dietary inclusion level of Pima (i.e., $12.8 \%$ ) numerically depressed performance of cows of both parities, these differences failed to reach statistical significance in these trials with few numbers of cows and for relatively short periods.

The FA composition of milk fat varied slightly in response to dietary treatments. The increase in the proportion of C18:2 in the milk fat of multiparous cows when $\mathrm{CrP}$ was increased in the diet was probably due to less efficient rumen biohydrogenation of $\mathrm{CrP}$ compared with WCS, as a consequence of a higher rate of ruminal passage due to the smaller particle size of $\mathrm{CrP}$, which reduced the ruminal hydrogenation of C18:2.

Further research is needed to determine whether these levels of $\mathrm{CrP}$ feeding can be sustained for a longer period of time without detrimental effects on animal productivity and/or reproductive performance.

\section{ACKNOWLEDGMENTS}

The authors thank D. Kominek, V. Vieu, and F. Sauers for preparing the diets, F. Stewart and W. Paroczai for collecting milk samples, and M. Calhoun, S. Kuhlmann and B. Baldwin at the Texas A \& M University, San Angelo, TX for performing the gossypol analyses. Special thanks to N. Tankersley and J. Renner for their technical support. Financial support was provided by the Supima Association of America and the California Agricultural Experiment Station (Davis). A gift from Tollenaar Holsteins, Elk Grove, CA and the advice of S. Carnes and E. Williams are greatly appreciated. This research was a contribution to Multi-state Research Project W-181.

\section{REFERENCES}

Association of Official Analytical Chemists. 1990. Official Methods of Analysis. 15th ed. AOAC. Washington, DC.

American Oil Chemist's Society. 1985a. Determination of free gossypol. Official Method Ba 7-58 in Official and Tentative Methods of Analysis. 3rd ed. Am. Oil Chem. Soc., Chicago, IL.

American Oil Chemist's Society. 1985b. Determination of total gossypol. Official Method Ba 8-78 in Official and Tentative Methods of Analysis. 3rd ed. Am. Oil Chem. Soc., Chicago, IL.

Anderson, M. J., D. C. Adams, R. C. Lamb, and J. L. Walters. 1979 Feeding whole cottonseed to lactating dairy cows. J. Dairy Sci. 62:1098-1103.

Avila, C. D., E. J. DePeters, H. Perez-Monti, S. J. Taylor, and R. A. Zinn. 2000. Influences of saturation ratio of supplemental dietary fat on digestion and milk yield in dairy cows. J. Dairy Sci. 83:1505-1519.

Barraza, M. L., C. E. Coppock, K. N. Brooks, D. L. Wilks, R. G. Saunders, and G. W. Latimer. 1991. Iron sulfate and feed pelleting to detoxify free gossypol in cottonseed diets for dairy cattle. J. Dairy Sci. 74:3457-3467.

Blauwiekel, R., S. Xu, J. H. Harrison, K. A. Loney, R. E. Riley, and M. C. Calhoun. 1997. Effect of whole cottonseed, gossypol, and ruminally protected lysine supplementation on milk yield and composition. J. Dairy Sci. 80:1358-1365.

Brown, W., M. DeLuna, O. Lough, and R. Swingle. 1982. Long staple cottonseed compares favorably with short staple seed in University of Arizona dairy feeding trial. Arizona Dairy Newsletter. Sept. 3. Tucson.

Calhoun, M. C., and C. Holmberg. 1991. Safe use of cotton by-products as feed ingredients for ruminants: A review. Page 97 in Cattle Research with Gossypol Containing Feeds. L. A. Jones, D. H. Kinard and J. S. Mills, ed. Natl. Cottonseed Products Assoc., Memphis, TN.

Calhoun, M. C., J. E. Huston, S. W. Kuhlmann, B. C. Baldwin, Jr., W. Menges, B. S. Engdahl, D. N. Ueckert, and G. R. Engdahl. 1990. Increased erythrocyte fragility in cattle, sheep, and goats fed whole cottonseed. Page 30 in Sheep and Goat, Wool and Mohair, PR-No. 4780. Texas Agric. Exp. Stn., College Station.

Calhoun, M. C., S. W. Kuhlmann, and B. C. Baldwin, Jr. 1995a. Assessing the gossypol status of cattle fed cotton feed products. Proc. Pacific Northwest Animal Nutr. Conf., Portland, OR.

Calhoun, M. C., S. W. Kuhlmann, and B. C. Baldwin. 1995b. Cotton feed product composition and gossypol availability and toxicity. Proc. National Invitational Symp. on Alternative Feeds for Dairy and Beef Cattle, St. Louis, MO.

Cant, J. P., E. J. DePeters, and R. L. Baldwin. 1993. Mammary uptake of energy metabolites in dairy cows fed fat and its relationship to milk protein depression. J. Dairy Sci. 76:2254-2265.

Cass, Q. B., E. Tirtan, S. A. Matlin, and E. C. Freier. 1991. Gossypol enantiomer ratios in cottonseed. Phytochemistry 30:2655-2657. 
Cochran, W. G., and G. M. Cox. 1957. Page 536 in Experimental Designs. 2nd Ed. John Wiley \& Sons. New York, NY.

Coppock, C. E., J. K. Lanham, and J. L. Horner. 1987. A review of the nutritive value and utilization of whole cottonseed, cottonseed meal and associated by-products by dairy cattle. Anim. Feed Sci. Technol. 18:89-129.

Coppock, C. E., J. W. West, J. R. Moya, D. H. Nave, and J. M. LaBore. 1985. Effects of amount of whole cottonseed on intake, digestibility, and physiological responses of dairy cows. J. Dairy Sci. 68:2248-2258.

Cox, D. R. 1958. Planning of Experiments. John Wiley \& Sons. New York, NY.

Crocker, L. M., E. J. DePeters, J. G. Fadel, H. Perez-Monti, S. J. Taylor, J. A. Wyckoff, and R. A. Zinn. 1998. Influence of processed corn grain in diets of dairy cows on digestion of nutrients and milk composition. J. Dairy Sci. 81:2394-2407.

Dacie, J. V., and S. M. Lewis. 1968. Practical Haematology. 4th ed. J. and A. Churchill Ltd., London, England.

DePeters, E. J., and J. D. Ferguson. 1992. Nonprotein nitrogen and protein distribution in the milk of cows. J. Dairy Sci. 75:3192_ 3209.

DePeters, E. J., and J. P. Cant. 1992. Nutritional factors influencing the nitrogen composition of bovine milk: A Review. J. Dairy Sci. 75:2043-2070.

DePeters, E. J., S. J. Taylor, A. A. Franke, and A. Aguirre. 1985. Effects of feeding whole cottonseed on composition of milk. J. Dairy Sci. 68:897-902.

Gray, M. L., L. W. Greene, and G. L. Williams. 1993. Effects of dietary gossypol consumption on metabolic homeostatis and reproductive endocrine function in beef heifers and cows. J. Anim. Sci. 71:3052-3059.

Harfoot, C. G. 1978. Lipid metabolism in the rumen. Prog. Lipid Res. $17: 21-54$.

Harrison, J. H., R. L. Kincaid, J. P. McNamara, S. Waltner, K. A. Loney, R. E. Riley, and J. D. Cronrath. 1995. Effect of whole cottonseed and calcium salts of long-chain fatty acids on performance of lactating dairy cows. J. Dairy Sci. 78:181-193.

Harvey, J. W. 1989. Erythrocyte metabolism. Page 185 in Clinical Biochemistry of Domestic Animals. 4th ed. J. J. Kaneko, ed. Academic Press, New York, NY.

Hawkins, G. E., K. A. Cummins, M. Silverio, and J. J. Jilek. 1985. Physiological effects of whole cottonseed in the diet of lactating dairy cows. J. Dairy Sci. 68:2608-2614.

Hoffman, W. S. 1937. A rapid photoelectric method for the determination of glucose in blood and urine. J. Biol. Chem. 120:51-55.

Hron, R. J., H. L. Kim, M. C. Calhoun, and G. S. Fisher. 1999 Determination of (+)-, (-)-, and total gossypol in cottonseed by high performance liquid chromatography. J. Am. Oil Chem. Soc. 76:1351-1355

Joseph, A. E. A., S. A. Matlin, and P. Knox. 1986. Cytotoxicity of enantiomers of gossypol. Br. J. Cancer 54:511.

Kiesling, H. E., and D. D. Miller. 1985. Fuzzy and slick cottonseed for lactating dairy cows. Proc. West. Sect., Am. Soc. Anim. Sci. 36:458.

Kraml, M. 1966. Semi-automated determination of phospholipid. Clin. Chem. Acta 13:442-448.
Lindsey, T. O., G. E. Hawkins, and L. D. Guthrie. 1980. Physiological responses of lactating cows to gossypol from cottonseed meal rations. J. Dairy Sci. 63:562-573.

Marsh, W. H., B. Fingerhut, and E. Kirsch. 1957. Urea nitrogen autoanalyzer methodology. Amer. J. Clin. Path. 28:681-688.

National Research Council. 2001. Nutrient Requirements of Dairy Cattle, 7th rev. ed. Natl. Acad. Sci., Washington, DC.

Noftsger, S. M., B. A. Hopkins, D. E. Diaz, C. Brownie, and L. W. Whitlow. 2000. Effect of whole and expanded-expelled cottonseed on milk yield and blood gossypol. J. Dairy Sci. 83:2539-2547.

Osland, R. B., and E. P. Wagner. 1985. Apparent digestibility of linted vs. delinted whole cottonseed for dairy cows. Fresno State Univ. Bull., Fresno, CA.

Palmquist, D. L., and F. L. Schanbacher. 1991. Dietary fat composition influences fatty acid composition of milk fat globule membrane in lactating cows. Lipids 26:718-722.

Parodi, P. W. 1999. Conjugated linoleic acid and other anticarcinogenic agents of bovine milk fat. J. Dairy Sci. 82:1339-1349.

Reiser, R., and H. C. Fu. 1962. The mechanism of gossypol detoxification by ruminant animals. J. Nutr. 76:215-218.

Risco, C. A., P. J. Chenoweth, R. E. Larsen, J. Velez, N. Shaw, T. Tran, and C. C. Chase, Jr. 1993. The effect of gossypol in cottonseed meal on performance and on hematological and semen traits in postpubertal brahman bulls. Theriogenology 40:629-642.

Robertson, J. B., and P. J. Van Soest. 1981. The detergent system of analysis and its application to human foods. Pages 123-130 in The Analysis of Dietary Fiber in Food. W. P. T. James and O. Theander, eds. Marcel Dekker. New York, NY.

SAS. 1985. SAS User's Guide: Statistics Version 5 Edition. 1985. SAS Inst. Inc., Cary, NC.

Smith, N. E., L. S. Collar, D. L. Bath, W. L. Dunkley, and A. A. Franke. 1981. Digestibility and effects of whole cottonseed fed to lactating cows. J. Dairy Sci. 64:2209-2215.

Sullivan, J. L., J. T. Huber, R. L. Price, and J. M. Harper. 1993a. Comparison of digestibility, nutritive value, and storage characteristics of different forms of cottonseed in diets fed to lactating dairy cows. J. Anim. Sci. 71:2837-2842.

Sullivan, J. L., J. T. Huber, and J. M. Harper. 1993b. Performance of dairy cows fed short staple, Pima, and cracked Pima cottonseed and feed characteristics. J. Dairy Sci. 76:3555-3561.

Van Soest, P. J., J. B. Roberts, and B. A. Lewis. 1991. Methods for dietary fiber, neutral detergent fiber, and nonstarch polysaccharides in relation to animal nutrition. J. Dairy Sci. 74:3583-3597.

Velasquez-Pereira, J., L. R. McDowell, C. A. Risco, D. Prichard, F. G. Martin, M. C. Calhoun, S. N. Williams, N. S. Wilkinson, and P. Ogebe. 1998. Effects on performance, tissue integrity, and metabolism of vitamin $\mathrm{E}$ supplementation for beef heifers fed diet that contains gossypol. J. Anim. Sci. 76:2871-2884.

Willard, S. T., D. A. Neuendorff, A. W. Lewis, and R. D. Randel. 1995. Effects of free gossypol in the diet of pregnant and postpartum Brahman cows on calf development and cow performance. J. Anim. Sci. 73:496-507.

Wise, S. J., J. A. Velez, R. C. Stahringer, L. W. Gene, and R. D. Randel. 1991. Effects of diets containing free gossypol on erythrocyte fragility and packed cell volume in cattle. Am. Soc. Anim. Sci. South. Sect. 69:43 (Abstr.) 